\title{
ПОЛИТИКО-ПРАВОВЫЕ ИНСТИТУТЫ КАК ДРАЙВЕРЫ ЭВОЛЮЦИОННОГО РАЗВИТИЯ СОВРЕМЕННОГО СОЦИУМА
}

\author{
Равочкин Никита Николаевич1,2, \\ nickravochkin@mail.ru \\ ${ }^{1}$ Кузбасский государственный технический университет имени Т.Ф. Горбачева, \\ Россия, 650000, г. Кемерово, ул. Весенняя, 28 \\ 2 Кузбасская государственная сельскохозяйственная академия, \\ Россия, 650056, г. Кемерово, ул. Марковцева, 5
}

Равочкин Никита Николаевич, кандидат философских наук, доцент кафедры истории, философии и социальных наук Кузбасского государственного технического университета имени Т.Ф. Горбачева; доцент гуманитарно-правовых дисциплин Кузбасской государственной сельскохозяйственной академии.

В статье рассматривается проблематика политико-правовых институтов в контексте социально-философских исследований, связанных с развитием современных обществ по эволюционному пути. Актуальность подтверждается главным образом высоким уровнем ответственности, который возлагается на рассматриваемые институты в целях обеспечения ими социального порядка в условиях трудно прогнозируемого мирового развития. Таким образом, социально-философский анализ представляется крайне необходимым при прорисовке контуров общепланетарной ситуации. Предметом исследования является обоснование роли политико-правовых институтов как драйверов современного эволюционного развития мировых обществ. Объектом исследования выступают современные политико-правовые институты. Цель определена автором как выявление причин, обусловливающих необходимость политико-правовых институциональных преобразований, и уточнение значимости властных структур за эволюционное развитие общества. Для достижения поставленной цели используется собственная синтетическая методология, включающая философские, общенаучные и междисциплинарные методы, а также мир-системный подход. Представлены причины и факторы политико-правовых институциональных преобразований. Рассмотрены особенности исторического оформления современного расклада сил на мировой арене. Посредством сравнительного анализа показано, что самые распространенные модели государственного управления (автократия и демократия) требуют своего концептуального переосмысления, а их ключевые идейные основы должны быть включены в новые варианты социального устройства.

Ключевые слова: Институты, политико-правовые институты, общество, эволюция, модернизация, развитие, миросистема.

\section{Введение}

Сегодня ввиду усложнения происходящих в мире разнонаправленных процессов и становления новых оснований государственного устройства проблемы обеспечения устойчивости социальной системы и ее эволюционного пути развития приобретают характер фундаментальных для социальной философии. В ряде моих опубликованных работ было доказано, что институты представляют собой такие структуры, которые главным образом выполняют функции, обеспечивающие устойчивость общества как социальной системы [1-4]. Автор считает, что повышенные требования к ответственности, возлагаемой на политико-правовые институты за эволюционный вариант разви- 
тия, предполагает генеральную преемственность социальных преобразований, позволяющих с целью раскрытия необходимых для любых обществ возможностей, исходя, разумеется, из имеющихся ресурсов. В то же время следует указать, что ключевым из таковых ресурсов был и остается интеллектуальный капитал, позволяющий осуществлять идейную детерминацию необходимых преобразований. Сразу обговорим, что в данной работе постараемся свести к минимуму рассуждения на предмет того, почему одни идеи как результаты мыслительной деятельности интеллектуалов способны оказывать детерминационное воздействие, а другие нет, почему влияние одних и тех же идей не является одинаковым. Наконец, оставим за скобками вопрос о том, куда исчезают идеи, которые не детерминируют социальные процессы. В статье показано, почему именно политико-правовые институты являются драйверами эволюционного пути развития обществ. Причем автор в полной мере разделяет убеждения коллег о том, что сегодня выходу общества на прогрессивную магистраль могут способствовать и два других набирающих вес актора: благодаря гражданской самоорганизации и транснациональным корпорациям. Однако пока глубокое рассмотрение данных вопросов остается за пределами интересующей тематики. Более того, даже несмотря на подобную тройственную природу драйверов социальной эволюции в большинстве государств население предъявляет повышенные требования и связывает собственные ожидания с переходом на новый уровень общественного развития именно с государственными решениями и политико-правовыми институтами. Прагматизм, которым руководствуются сегодня многие обществоведы, также доказывает, что выбранная группа институтов с большей долей вероятности способна решить острые социальные задачи. Главные составляющие этих институтов - динамично развивающаяся политика и распространяющееся на весь перечень общественных отношений право - де-факто обеспечивают себе нормативное присутствие во всех других сферах, в связи с чем они, по сути, находятся чуть выше институтов из остальных областей общественной жизни.

Итак, на протяжении всей истории существования человечества, начиная от процессов сапиентации и политогенеза, его непрерывно сопровождают те или иные политико-правовые институты. Возникнув в глубокой древности при переходе от потестарных обществ к первым государственным формам, они были учреждены в первую очередь для регуляции различных аспектов жизнедеятельности общества, постепенно расширяя свой нормативный и прочий функционал. Логично, что на таком историческом отрезке одни институты давно утратили свою актуальность, вследствие чего были упразднены, а другие, проходя через обновление, продолжают существовать и организовывать социальное бытие. Кроме этого, уже отмеченный мной турбулентный характер мирового развития в последние десятилетия приводит к существенными практически перманентным трансформациям политико-правовых институтов. Оценки результатов этих многочисленных процессов могут быть как успешными и способствовать дальнейшей оптимизации взаимодействия общества и государства или же характеризоваться весьма низкой эффективностью и результативностью.

Трудно не согласиться с очевидным (да это и признается большинством зарубежных и отечественных исследователей), что современный глобализационный контекст фактически обусловил перманентность изменчивости политико-правовых институтов. Тем не менее социально-философская работа прежде всего предполагает выявление причин, в соответствии с которыми в одних случаях изменения являются успешными, а в других не могут признаваться таковыми. К слову, данный вопрос пока еще остается малоизученным в современной научной литературе. Более того, не до конца проработаны направления детерминант, обусловливающих саму необходимость осуществления 
изменений, как механизмов и факторов, влияющих на успешность изменений. Таким образом, налицо сформировавшееся противоречие между признанием необходимости реформирования политико-правовых институтов, повышения их эффективности, адаптации к постоянно меняющимся социальным потребностям и отсутствием понимания того, как именно воплотить эти новации в жизнь, чтобы изменения не привели к негативным результатам. Разрешение указанного противоречия, еще и в условиях трудной предсказуемости и прогнозирования социальных процессов, обусловливает актуальность статьи.

Цель исследования сформулирована как выявление причин, обусловливающих необходимость политико-правовых институциональных преобразований, и уточнение значимости рассматриваемых институтов за эволюционный вариант общественного развития.

\section{Обзор теоретических источников}

Прежде всего, мне хочется показать сущность процесса политико-правовых институциональных образований и вскрыть факторы, которые их обусловливают. В современной научной литературе понятие «институт» представлено целой палитрой определений, восходящих порой до взаимоисключающих трактовок. Однако в настоящей работе я буду придерживаться неоинституциональной трактовки институтов: «Правила игры в обществе или, если говорить более формально, это созданные человеком ограничения, которые формируют человеческое взаимодействие» [5, с. 97-98]; «правила, определяющие особенности реализации политической игры» [6, с. 7]. Преимущества указанных дефиниций заключаются в том, что они позволяют выделить необходимые сущностные характеристики институтов:

1.Как ограничения они устремлены на реализацию регуляторной функции. Во многом это подчеркивает предписывающий характер рассматриваемых установлений, который достаточно отчетливо можно увидеть и в самой политико-правовой сфере, тесно связанной с властными полномочиями. В частности, политико-правовые институты определяют объем избирательных прав и круг социальных агентов, которые получают доступ на арену, где ведется борьба за власть. Затем рассматриваемые институты определяют ее последующее распределение и процедуры принятия решений на различных уровнях [6, с. 7].

2. Будучи инициированы самим человеком, институты как «правила игры» в гораздо меньшей степени зависят от других факторов (например, от географических, которые находятся вне пределов человеческого контроля), что (при релевантности культуральным параметрам) позволяет им оставаться устойчивыми в (относительно) долгосрочной перспективе. В самом деле, трудно согласиться с тем, что необдуманный импорт институциональных практик, не адаптированных под конкретные социокультурные реалии, пусть даже самых передовых, однозначно приведет к эффективному развитию того или иного государства по принципу «раз и навсегда».

Описывая изменения, происходящие с институтами в целом, некоторые исследователи отмечают, что эти трансформационные процессы могут быть описаны посредством метафор, применяемых относительно эволюции природного мира [7]. Напомню, что в самом общем виде любая биологическая эволюция представляет собой «процесс, включающий как действие внеположных организму сил (естественный отбор и выживание наиболее приспособленных), так и внутренние генетические мутации и изменения организмов, популяций и видов, в том числе на основе случайностей и регулярных «ошибок», в случае «удачи» или по стечению обстоятельств закрепляемых и накапливаемых» [7, с. 34]. 
В свою очередь, другие исследователи, принадлежащие к «обобщенному дарвинизму», делают акцент на том, что применение термина «эволюция» относительно институциональных преобразований допускается, причем именно в буквальном смысле [8, с. 315]. Сторонники данного подхода подчеркивают, что биологическая и институциональная эволюции не тождественны и тем более не идентичны друг другу, т. к. биология - это «всего лишь одна из областей, в которой протекают эволюционные процессы» [8, C. 315]. Можно сказать, что эволюцию как и энергию можно отнести к группе универсальных феноменов, потому их можно наблюдать практически во всех сферах жизнедеятельности общества. Просто в каждой из областей данные явления будут подчиняться сугубо определенным законам. Приведя такую аналогию, показано, что любые трансформации политико-правовых институтов не могут укладываться в какиелибо линейные модели объяснения, которые сегодня попросту не могут дать плодотворных описаний. Анализ современной динамики свидетельствует о том, что сегодня трансформационные процессы, происходящие с институтами, выглядят куда сложнее, чем, например, несколько десятилетий назад, и им свойственны многоуровневость, неоднородность, разнонаправленность и противоречивость.

Сообразуясь с общеизвестной позицией об открытости социальных (под)систем, приведу мнение С.С. Япарова, выделяющего три группы факторов, лежащих в основании политико-правовых институциональных трансформаций [9, с. 187]:

1. Экономические институты, генерирующие и формирующие различные стимулы, создают для ключевых экономических агентов условия деятельности, что, в свою очередь, влияет на инвестиции в человеческий капитал, технологии и организацию производственных процессов. В итоге институты этой сферы всегда обусловливают особенности распределения ресурсов в конкретном обществе, что на практике способствует повышению доступа к таковым для одних социальных групп и создает целый ряд ограничений для других. Неравенства при доступе к ресурсам приводят к многочисленным конфликтам интересов между представителями практически различных социальных групп, за успешность регулирования которых ответственна сфера политики и права.

2. Обладание властными полномочиями, которые могут быть распределены между самими политико-правовыми институтами, но также их некоторый объем может достаться какой-либо группе лиц (например, интеллектуалам), участвующих при определенных условиях в реализации тех или иных социальных преобразований. Отметим, что Япаров выделяет два случая, при которых возможна концентрация властных полномочий у таковых групп: во-первых, когда в руках социальной группы накапливаются значительные экономические ресурсы, во-вторых, в ситуациях обострения социальной несправедливости, при которых группы и даже целые страты оказываются полностью исключенными из системы распределения ресурсов. В таких реалиях социальные группы, непосредственно не принадлежащие к политико-правовой сфере, накапливают реальную власть и получают возможности использовать эту силу против своих оппонентов, что позволяет им (чаще всего, коренным образом) реформировать политикоправовые установления, поскольку именно власть «является ключевым фактором, определяющим эволюцию формальных институтов» [5, с. 188; 9, с. 188].

3. Сама действующая элита инициирует и осуществляет желаемые преобразования с целью не простого сохранения, но усиления легитимности собственных властных полномочий. Наконец, внутри представителей истеблишмента, осуществляющего управления государством, может произойти раскол, который приведет к революционному варианту институциональных преобразований $[5,9]$. 
Итак, в основании трансформаций политико-правовых институтов лежит целая совокупность факторов, тесное взаимодействие которых обусловливает последующие изменения образа государства и общества. Механизм трансформаций политикоправовых институтов может быть представлен следующим образом (рисунок):

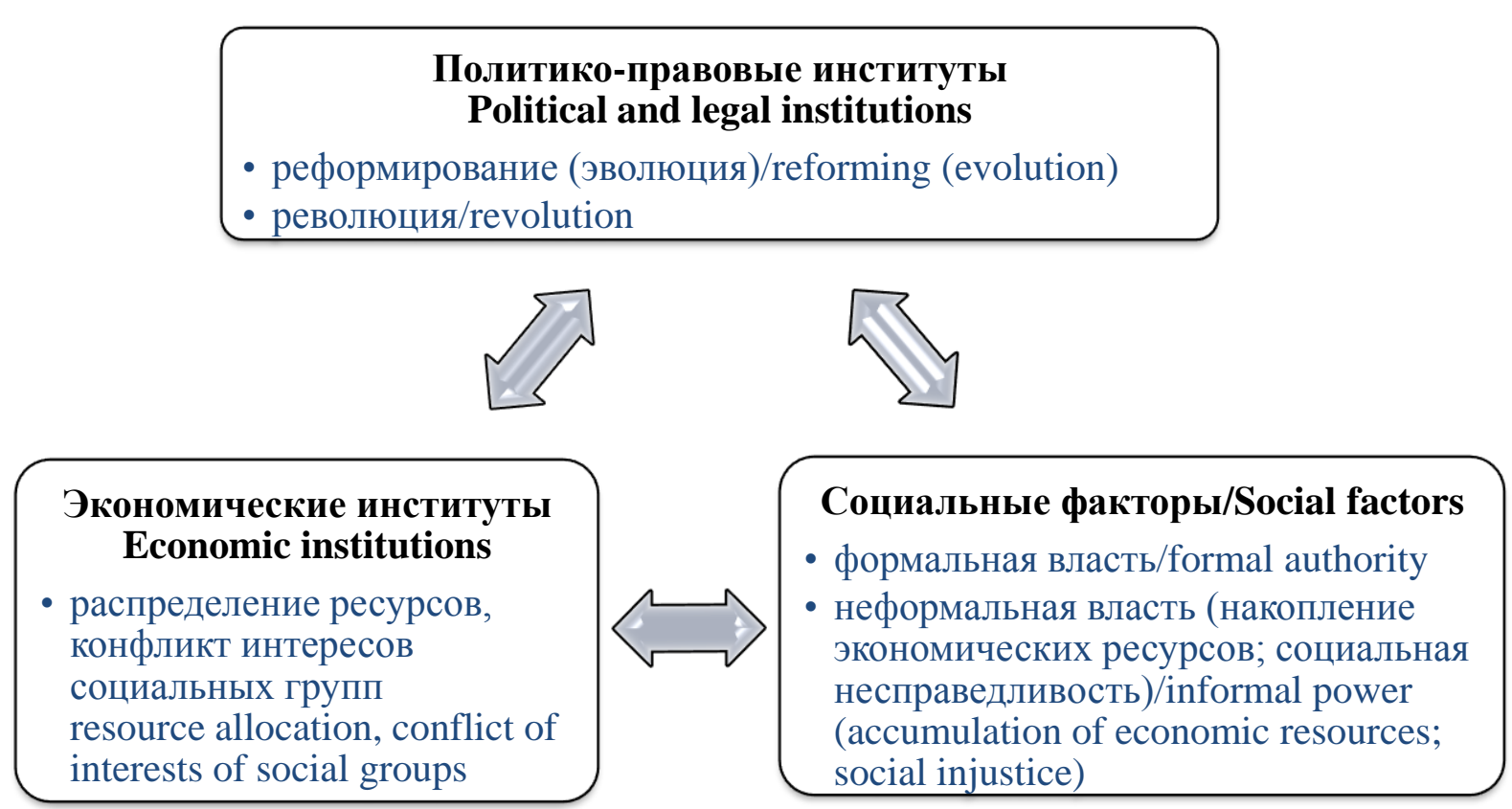

\section{Рисунок. Механизм трансформаций политико-правовых институтов Figure. Mechanism of transformations of political and legal institutions}

Важно добавить, что именно социальным факторам, теснейшим образом связанных с социосферой, следует отвести ведущую роль в осуществлении политикоправовых институциональных изменений и конструировании общества вцелом. Поясняю это тем, что развитие человечества, расширение сферы коммуникаций, генерирование новых идей и фреймов - все это формирует новые потребности, обусловливая необходимость трансформации политико-правовой структуры. Возвращаясь к биологическому дискурсу, можно сказать, что в институциональном развитии идеям отводится та же роль, которую играют мутации в процессе биологической эволюции, обусловленной способностями живых организмов отвечать все новым и новым вызовам [6, с. 11].

Для наглядности в качестве примера взаимодействия различных факторов приведен опыт Европы, переходящей от средневекового типа к капиталистическому. Вплоть до XVII столетия главным политико-правовым формальным институтом являлся институт монархии. Таким образом, вся власть была сосредоточена в руках соответствующих правителей, которые «часто использовали свои полномочия, чтобы ущемлять права производителей, усиливать налоговое бремя, а также отдавать производительные ресурсы общества своим союзникам в обмен на политическую поддержку» [9, с. 188]. На практике такое положение дел свидетельствовало об отсутствии экономических стимулов для развития человеческого капитала и производств. Однако в связи с развитием международной торговли купцам и другим членам торговых гильдий удалось накопить внушительные ресурсы, что обеспечило концентрацию в их руках реальной власти, приведшей к «Славной революции», а затем и к глубоким реформам, во многом заложившим основы современного типа политико-правового устройства. Реальными 
последствиями этого события стали ограничение власти монарха и принятие «Билля о правах», в котором впервые на законодательном уровне были закреплены права человека. Преобразования, которые произошли с политико-правовыми институтами, распространились на сферу экономики. В частности, были закреплены права собственности на землю, что, в свою очередь, способствовало развитию человеческого капитала, внедрению технологий и привело к вполне логичному господству нового типа социума, одним из наиболее ярких и значимых для мировой истории олицетворений которого стала «Промышленная революция».

Получается, что преобразования политико-правовых институтов не просто необходимы, а витальны для любых обществ, встающих на эволюционную магистраль своего развития. Следовательно, распространенные убеждения о консервативном характере норм права и проводимой политики и, что главное, необходимости их сохранения в таковом виде выглядят несостоятельными. Хотя вполне вероятно, что такие заблуждения могут быть развеяны благодаря обращению к концепциям постепенной модернизации и/или технологиям социальной инженерии [10-12]. С.С. Япаров также отмечает, что «до тех пор пока усилия политической элиты будут направлены на недопущение изменения в политическом устройстве, институциональные преобразования будут направлены не на решение существующих проблем в экономике, а на укрепление позиций действующей власти» [9, с. 181]. Заключением отсюда будет тезис, в соответствии с которым изменения политикоправовых институтов и их последовательная адаптация под меняющиеся требования социума выступают средством обеспечения выживания государства как суперинститута.

\section{Исторические особенности политико-правового институционального порядка в периферийных странах и странах ядра}

Выше было рассмотрено, что институциональные изменения носят универсальный характер, поскольку в той или иной форме они протекают во всех странах мира, тогда как эволюция - это желаемый вариант данных изменений. В соответствии с этим рассмотрим уже озвученный вопрос: «Почему в одних странах трансформации политико-правовых практик являются успешным и отвечают изменившимся социальным запросам и вызовам современного мира, а в других - нет?».

Современные исследователи-обществоведы все чаще связывают эффективность политико-правовых институциональных преобразований по эволюционному пути со способностью национальных государств наращивать физический и человеческий капитал, развивать науку и внедрять новейшие технологии [9, с. 181]. Поскольку реализация любых инициатив носит уникальный, можно даже сказать, «штучный» характер, то и сами политико-правовые институты будут сущностно отличаться в различных обществах (вне зависимости от оснований классификации). Более того, один и тот же политико-правовой институт может быть не похож на аналогичный, причем даже в реалиях демократических обществ, где они будут выполнять совершенно различные функции и отсюда оказывать качественно другое влияние на общество, сказываясь на распределении власти между соответствующими акторами.

Объяснение специфики особенностей институционального развития в различных странах может быть осуществлено в логике мир-системного анализа И. Валлерстайна. По мнению ученого, современная миросистема представляет собой «мироэкономику, и она является по определению капиталистической по своей форме» [13, с. 57]. Уже упомянутый мной Япаров считает, что формирование современной миросистемы было связано с европейской колонизацией, начавшейся в конце XV в. и проходившей в двух направлениях [9, с. 184]: 
1. Центральная Америка, Африка, Карибский бассейн, где европейцы создавали периферийные страны, так называемые «добывающие государства». Целесообразно отметить, что эти территории привлекали европейцев по большей части как источники природных богатств. Освоившим школьный курс географии и истории известно, что данные земли использовались колонизаторами для выращивания хлопка, сахарного тростника и какао, а также обладали значительными ресурсами (древесина) и запасами золота и алмазов. Более того, несмотря на официальный запрет европейских стран, в этих странах была достаточно развита работорговля $[9,14]$. Соответственно, политикоправовые институты, учреждаемые на этих территориях, были направлены не на защиту частной собственности или обеспечение системы сдержек и противовесов, защиту прав и свобод граждан, но на защиту привилегированного положения, частной собственности элит, тогда как «подавляющее большинство населения сталкивается со значительными барьерами, препятствующими их участию во многих экономических процессах» [9, с. 184]. Таким образом, главной целью истеблишмента выступало создание высокоцентрализованного государственного аппарата, что в итоге обеспечивало долгую гегемонию его представителей, но одновременно с этим приводило к ущемлению прав коренных народов.

2. Колонии, в которых европейцы поселились в большом количестве: США, Канада, Австралия, Новая Зеландия. Здесь акцент был сделан на принципы свободы и защиту имущественных прав. Институты создавались и разрабатывались для собственного проживания. Впоследствии некоторые из этих территорий стали странами «ядра» в существующей миросистеме [9].

Иначе говоря, политико-правовой облик современных национальных государств во много обусловлен особенностями исторических процессов, главным образом за счет колонизации, в результате которой многие национальные институты, сформированные на колониальных территориях, были разрушены или же кардинально трансформированы под влиянием европейцев в сторону низкой эффективности для жителей данных земель. Действительно, о каких позитивных оценках можно говорить, если люди, создавшие первые правовые системы, попросту «забыли» о правах жителей подконтрольных им территорий. В свою очередь, на местах непосредственного проживания европейцев были созданы такие модели политико-правовых институтов, которые были максимально приближены к своим европейским вариантам, что объяснялось стремлениями метрополий обеспечить эффективную регуляцию различных взаимодействий.

К сегодняшнему дню сложилась ситуация, при которой в странах так называемого «ядра» (мировые либеральные демократии) сложились действенные политикоправовые институты, тогда как в государствах «полупериферии» и непосредственно самой «периферии» функционирующие политико-правовые институты попросту не отвечают вызовам современного мира. Так, изучая провалы внедрения политикоправового института электронного правительства за пределами стран «ядра» [15], автор пришел к выводам, что неудачи данной инициативы детерминированы целым комплексом факторов:

- проблемы, связанные с инфраструктурой;

- риски безопасности хранения персональных данных;

- квалификационные риски;

- организационные проблемы, недостатки координации различных органов государственной власти;

- высокая стоимость внедрения. 
Однако в целом проблемы эволюционного политико-правового институционального развития в рассматриваемых странах намного глубже. Главное, что они заложены в самих основах организации государственного устройства, тяготении стран к автократии, несовершенстве, неразвитости демократических процедур.

\section{Эффективность/неэффективность политико-правовых институтов в демократических и автократических странах}

Анализ богатого материала мировой истории свидетельствует, что в ситуациях отдаленности колоний от «центра управления» местная элита практически всегда тяготеет к автократии и болезненно воспринимает любые попытки делегировать властные полномочия населению, воспринимая это как снижение авторитета местного правительства [16, с. 41], тем самым погрязая в коррупции. Как отмечают государственные чиновники этих государств, «коррупция широко практикуется даже в тех министерствах, которые изначально были призваны бороться с ней» [17, с. 160].

Выше было показано, что одним из оснований трансформаций политикоправовых институтов является распределение благ, иначе говоря, доступ к ресурсам. Как правило, государства, как демократические, так и автократические, реализуют два основных подхода к реализации политики, связанной с распределением материальных благ [6, с. 8]:

1. Политика «защиты прав собственности», подразумевающая поощрение развития различных отраслей как средства экономического роста, что должно привести к повышению благополучия общества и преодолению социального неравенства.

2. Политика «перераспределения», направленная на так называемое «выравнивание» ресурсов в обществе. Основными средствами такого выравнивания выступают широкомасштабные программы, предоставление общественных благ и регулирование рыночных и экономических институтов. По мнению приверженцев этого варианта, адекватная политика перераспределения ресурсов и соответствующая государственная поддержка обеспечивают более тесную взаимосвязь между личностью и политикоправовыми институтами, в большей степени соответствуя потребностям личности и общества для достижения социальной справедливости и преодоления социального неравенства [6, с. 8]. Кроме этого, данный вариант обеспечивает модернизацию здравоохранения и образования, повышает общий уровень развития населения в целом и отдельных социальных групп, которые прежде не имели доступа к ресурсам.

Отметим, что изначально политика защиты прав собственности выступала основой либерально-демократических стран. Сегодня же оба указанных направления политики реализуются как в демократических, так и автократических странах, однако для стран ядра в большей степени свойственно тяготение к усилению защиты прав собственности, для периферийных стран - политика перераспределения ресурсов, которая, к слову, часто воспринимается как несправедливая.

Широкое распространение получила исследовательская позиция по поводу того, что в большинстве случаев успешность преобразований, осуществляемых с политикоправовыми институтами, напрямую коррелирует со степенью демократизации общества и реальным соответствием протекающих в нем процессов данному режиму. К примеру, насколько эффективность трансформаций может быть сопряжена с функционированием института делегирования полномочий и/или обеспечения прав и свобод гражданина. Однако следует помнить, что идея этого института, пусть и предложенная с учетом корректировок на самые современные события, и ее реализация никогда не совпадают и не означают одно и то же. Между тем, исследователи убеждены, что в демо- 
кратических обществах функционирование институтов происходит на более высоком уровне и отличается большей результативностью для них. В частности, они полагают, что своевременные политико-правовые институциональные преобразования всегда будут сопровождаться повышением экономического благосостояния личности, развитием человеческого капитала, улучшением функционирования других социальных институтов и практик [18]. В то же время невозможно согласиться с данным тезисом полностью, поскольку история и современный мир щедры на примеры декларативной демократии и иных ее вариантов, когда данная траектория используется главным образом для собственных целей и интересов, преследуемых властными элитами.

Тем не менее я не могу отрицать, что на протяжении длительных десятилетий демократию можно считать действительно позитивным инструментом, который предоставляет социальным группам широкий спектр возможностей участия в управлении государством, а также выражать, формировать и аккумулировать политическую власть, непосредственным образом влияя на повышение эффективности и результативности учрежденных политико-правовых институтов [19, с. 157]. Руководствуясь многими основными положениями эволюционного подхода, демократия рассматривается как официальное и легитимное делегирование властных полномочий обществу и личности. Уровень сформированности и развития политической демократической культуры напрямую обусловливает потребности в форме правовой защиты либо в делегировании реальных полномочий, обладая которыми большинство населения на деле инкорпорируется в политико-правовое пространство. Впрочем, демократия действительно выступает одним из достижений социальной мысли и действенным средством, которое позволяет государствам сворачивать с революционного пути осуществления политикоправовых институциональных трансформаций. Полагаем, что теперь стало понятно, почему представители социально-гуманитарных наук связывают причины эффективного преобразования политико-правовых институтов в либерально-демократических странах с более высокой эффективностью реализации политики защиты прав. В целом это совпадает с моим убеждением о более полном понимании соответствующих идей и их последующим воплощением.

В то же время в странах периферии (куда реже - в государствах полупериферии) подобные институты либо вовсе отсутствуют, либо все еще находятся на начальных стадиях своего становления, а также сопряжены с куда более разнообразными модификациями реализуемой политики распределения благ. Например, согласно концепции о «срединном избирателе», в ситуациях, когда доход обычного избирателя падает, налоговое бремя растет (при этом средств для личного потребления остается гораздо меньше), государство сталкивается с необходимостью повышения доступности и качества социальных услуг [20, с. 2]. Примечательно, что в авторитарных системах распределение ресурсов не играет решающей роли, поскольку большая часть избирателей попросту исключена из ситуаций, связанных с принятием решений, как раз для того, чтобы исключить их из рассматриваемых дистрибутивных процессов [6, с. 9]. Конечно, автократические режимы тоже осуществляют перераспределительную политику, однако главной целью выступает не успешное реформирование политико-правовых институтов, а стремления элит как можно дольше оставаться у власти, тем самым увеличивать свое собственное богатство.

Отмечу, что при распределении ресурсов демократические общества используют такие передовые инструменты, как общественные дебаты, критика действий властей. В процессе общественного обсуждения формируется система представлений о социальных нуждах и потребностях, которые впоследствии начинают фигурировать на по- 
литической арене, в предвыборных кампаниях, выступлениях отдельных политиков (правда, порой с манипулятивными целями). Помимо упомянутой вовлеченности населения в управление государством, это прежде всего обеспечивает обновление системы ценностей и идейного инструментария для создания будущих моделей реализации социальных преобразований и принятия государственных решений. Кроме того, такие демократические процедуры, как свободные конкурентные выборы, соблюдение принципа верховенства закона, способствуют снижению коррумпированного и дискриминирующего поведения политических элит. Обозначение обновленных или новых потребностей ввиду обостряющихся социальных вызовов способствует тому, что мнение самых различных групп, даже наиболее обездоленных, будет услышано, представлено. Следовательно, общественное мнение учитывается в реализации политики в соответствии с нуждами и потребностями граждан [21, с. 9], заставляет политиков действовать более ответственно и выступать от имени общества, которое они представляют. Но в то же время, даже если успех демократических режимов зависит от эффективности перераспределения ресурсов, то это далеко не всегда означает полную удовлетворенность всех социальных потребностей различных групп.

Реалии современных автократических режимов таковы, что правящий класс диктует волю народу «сверху», а практически любая оппозиция подавляется (кроме той, что создается властями для видимости), и сводятся на «нет» свобода слова и выражение собственного мнения. Государственный аппарат используется исключительно для обеспечения благополучия правящих элит, обращение к перераспределительным мерам относительно других социальных групп происходит только в случаях, когда они приносят пользу властям, т. е. если обеспечивают сохранение власти правящим элитам и/или способствуют повышению их благосостояния [22, 23], тогда как представительность, ответственность, компетентное политическое и административное регулирование, как правило, в авторитарных режимах отсутствуют [24, с. 313]. Соответственно, если в демократических странах делегирование полномочий и вовлеченность в принятие политических решений позволяют предотвратить усугубление социальной несправедливости, которое может привести к росту напряжения и массовым неудовольствиям, выливающимся в каскады бунтов, восстаниям и революциям, то в автократических отмечается обратная ситуация, при которой напрочь отсутствует учет мнения населения, а усиление несправедливости в распределении ресурсов распространяется почти на все сферы общественной жизни.

Итак, из приведенного мной абриса напрашивается логичный вывод: в большинстве демократических стран институциональные преобразования в сфере политики и права достаточно осуществляются в логике эволюционного подхода и с обращением к новым идеальным моделям, создание которых происходит через осмысление современных вызовов и потребностей общества. Подобный подход позволяет адаптировать трансформации под новые конфигурации общественного устройства. Закономерно, что в автократических государствах подобные изменения, как правило, приобретают материальную возможность преимущественно «снизу» и революционным путем, который в ситуациях отсутствия опыта политико-правового строительства может приводить не только к позитивным, но и к негативным последствиям, написано в одной из работ автора [10]. Данные причины во многом отражают реальность функционирующих создаваемых новыми агентами политико-правовых институтов, характеризующихся в большинстве случаев низкой эффективностью. Более того, как показывает практика, при их создании новые элиты весьма редко способны учесть весь спектр реалий и согласовать позиции широких социальных групп, что, по сути, только умножает риски новых возмущений. 
Дополнительно следует отметить, что достаточно часто в результате революций и бунтов, обусловленных ввиду отсутствия доступа большинства населения к ресурсам и вследствие этого оцениваемых ситуаций как «несправедливые», обновление политикоправовых институтов нельзя характеризовать как «эволюционное». По большому счету, такие преобразования могут быть категориально определены как «стагнация» и даже «деградация». Для этого достаточно посмотреть на пример современной Украины: неадекватное распределение благ, отсутствие доступа к ресурсам, социальная несправедливость - все это привело к протестам и целой революции. Однако на деле после соответствующих событий фактического обновления политико-правовых институтов не произошло, но зато к власти пришли новые лица, а сама система перераспределения ресурсов не изменилась. Другими словами, поменялся только облик властного истеблишмента. Как следствие, отсутствие глубоких структурных изменений сопровождается усилением недовольства, но уже иных социальных групп, которые могут стать материальной силой очередного протестного движения, умножающего все палитру рисков общественной жизни.

Тем не менее в последние годы, несмотря на очевидные преимущества демократии как варианта организации государственного устройства, данные ценности, воспринимаемые многими агентами в качестве универсальных и однозначно приводящих к успеху политико-правовых институциональных преобразований, все чаще подвергаются сомнениям. Так, в работах Alesina и Rodrik [25], Barro [26] и Acemoglu и Robinson [27] утверждается, что автократические режимы могут быть более эффективными при управлении ресурсами для преодоления провалов, наблюдаемых в функционировании экономических институтов. По сути, мобилизационный потенциал, применяемый властными акторами, обеспечивает стабильный рост и, как следствие, более эффективное строительство, что можно экстраполировать на будущее обновление политикоправовых институтов.

В отечественной науке ценности либеральной демократии также неоднократно подвергались критическому осмыслению. В частности, в работах С. Караганова разделяется мнение зарубежных авторов, что в отдельных ситуациях автократии обладают гораздо более высоким мобилизационным потенциалом, нежели демократии. Вообще, как считает Караганов, любые теории объяснения политико-правового институционализма, представленные в западноевропейской литературе, «либо устарели, либо изначально неадекватны из-за осознанного или даже неосознанного стремления их создателей служить интересам своих стран или их элит» [28]. Данный тезис совпадает с позицией автора, связанной с необходимостью создания новых подходов к организации институционального порядка, которые бы в полной мере учитывали контекст, прежде всего своевременность реализации преобразований (актуальные социальные вызовы), культуральные параметры и экспектации широких групп и слоев населения.

Помимо этого, по мнению автора, традиционное разделение стран на основе оппозиции «автократия-демократия» сегодня устарело, является слишком упрощенным и вступает в противоречия с современным мировым развитием, что существенным образом затрудняет однозначное отнесение каждого конкретного государства к странам первого или второго типа. Многие эксперты убеждены, что флагман ценностей либеральной демократии, продуцируемых главным образом США, в самом деле, переживает не лучший этап своего исторического развития, следовательно, требует критического осмысления и реконструкции. По словам профессора Чикагского университета А. Цыганкова, «корень проблем - в дискредитации демократического и гражданского компонентов американской системы» [29]. Сегодня США из либеральной 
демократии превратилась в «страну корпораций, в которой правят военнопромышленные и медийные элиты, способные навязать обществу свои приоритеты», «в олигархию, управляющую плохо информированными гражданами» [29]. Иначе говоря, в данном случае, в отличие от стран периферии, в которых изменения политикоправовых институтов осуществляются в результате усиления социальной несправедливости и отсутствии доступа к ресурсам, трансформации политико-правовой реальности в Соединенных Штатах осуществляются под давлением упомянутых во введении новых агентов влияния (транснациональные корпорации), сосредоточивших в своих руках реальную политическую власть. По большому счету эта ситуация во многом напоминает ту, что сложилась в средневековой Европе, когда главной силой социальных преобразований стала буржуазия, которая стала ведущей силой целой череды прокатившихся по континенту революций. Буржуазии удалось победить за счет того, что она была ближе к широким социальным массам и наряду с ними противостояла монархии.

Разумеется, достаточно сложно дать валидный прогноз, к чему именно приведут происходящие сегодня политико-правовые трансформации и какой облик (пост) современности они сформируют. Американские транснациональные корпорации находятся на вершине условно называемой «пищевой цепочки», а ее наиболее ярким представителем является президент Дональд Трамп, личность которого воспринимается крайне противоречиво. По словам Б. Ло, Трамп является тем президентом, «чья продолжительность внимания коротка, чье невежество в отношении иностранных дел огромно, для которого дикие колебания политики являются добродетелью» [30]. Также Цыганков подчеркивает, что «в американской президентской истории трудно назвать человека со столь сильной концентрацией эгоцентризма, непрофессионализма и готовности опорочить любого из своих критиков. Пророчества русских мыслителей о грядущем торжестве хама в России и Европе, кажется, оказались актуальны и для Америки» [29]. Даже принимая во внимание эту посылку о противоречивости образа представителя олигархии, сложно предположить, что текущие изменения политико-правовых институтов будут успешны и результативны, как это было прежде.

Вместе с тем кризисные тенденции, с которыми сегодня столкнулись многие западные страны, вовсе не означают утраты актуальности самой идеи либеральной демократии как оптимальной системы взаимодействия государства и личности при посредничестве политико-правовых институтов. В то же время мейнстрим современной философской мысли показал, что самые различные общества выступают заказчиком новых идей для реализации глубоких структурных преобразований в эволюционном ключе. С точки зрения автора, это будет возможным, в том числе и благодаря синтезу лучших, т. е. проверенных временем, мыслительных конструктов, фундировавших различные (макро)региональные либеральные демократии с неукоснительным соблюдением на практике приоритета права частной собственности и уважения индивидуальности личности, но в то же время и повышения роли государства и властных акторов в вопросах достижения социальной справедливости. В принципе подобный опыт сегодня успешно применяется в скандинавских странах и, соответственно, может быть учтен в процессах политико-правовых институциональных преобразований.

\section{Заключение}

Таким образом, на основании проведенного анализа можно сделать вывод, что процесс политико-правовых институциональных преобразований в современном обществе осуществляется постоянно и повсеместно. Желаемым образом таковых изменений будет являться выход государств на магистраль социальной эволюции, за которую, как 
было показано в основной части работы, в большей степени ответственны именно политико-правовые институты. В основании политико-правовых институциональных трансформаций лежат различные факторы, доминирующее место среди которых занимают социальные (несправедливость распределения благ и ограничение доступа к ресурсам порождает столкновение групповых интересов).

Эффективность и результативность преобразований политико-правовых институтов и всего социума в целом во многом зависят от особенностей исторического формирования современной миросистемы. Так, в бывших колониях, которые во времена колонизации были выбраны как места проживания европейцев, политико-правовые институты изначально создавались для защиты интересов населения, тогда как в странах, которые использовались для добычи ресурсов, ставших перифериями, рассматриваемая группа институтов закрепляла социальное неравенство и способствовала угнетению коренного населения.

На сегодняшний день обновление политико-правовых институтов в странах ядра, как правило, осуществляется на основании тех идей, в которые вплетены ценности либеральной демократии, в полупериферийных и периферийных - в парадигме автократического стиля управления. Традиционно успешность реформирования политикоправовых институтов в демократических обществах связывается с вовлечением широкой общественности в процессы выработки принимаемых на различных уровнях решений, что позволяет избегать нарастания социального недовольства и адаптировать внутреннюю политику в соответствии с социальными потребностями и запросами. Одновременно с этим остается непонятным, каким образом будут проходить трансформационные траектории западных политико-правовых институтов, когда США как ярчайший образец либеральной демократии оказались в кризисной ситуации. Однако это отнюдь не снижает актуальность и значимость идей либеральной демократии, поскольку в целях создания идей эволюционного развития задает императив обращения к опыту скандинавских стран. Целесообразность этих практик видится в том, что этим государствам удалось органично синтезировать политико-правовые институты с другими практиками и нивелировать социальное напряжение. Таким образом, вне зависимости от того, в какой именно сфере начинаются преобразования (в качестве перспективных направлений укажем технологическую, социальную и информационную области человеческой жизни), успех и эволюционный вариант развития обществ в наибольшей степени завязаны именно на политико-правовых институтах.

\section{СПИСОК ЛИТЕРАТУРЫ}

1. Равочкин Н.Н. Влияние философских идей на политико-правовые институты в свете исторической макросоциологии // Вестник Тверского государственного университета. Серия «Философия». 2019. - № 2 (48). - С. 30-40.

2. Равочкин Н.Н. Идейная детерминация политико-правовых институциональных преобразований в XXXXI вв. // Контекст и рефлексия: философия о мире и человеке. - 2019. - Т. 8. - № 4А. - С. 150-165.

3. Равочкин Н.Н. Институт как объект социально-философского анализа // Манускрипт. - 2019. Т. 12. - № 8. - С. 109-113.

4. Равочкин Н.Н. Онтологические и аксиологические основания политико-правовых нововременных институтов // Современная наука: актуальные проблемы теории и практики. Серия «Познание». 2019. - № 5 (92). - C. 121-126.

5. North D.C. Institutions // The Journal of Economic Perspectives. - 1991. - V. 5. - № 1. - P. 97-112.

6. Vollmer S., Ziegler M. Political institutions and human development does democracy fulfill its 'constructive' and 'instrumental' role? - The World Bank Development Research Group Macroeconomics und Growth Team (Policy Research Working Paper 4818), 2009. - 47 p. URL: https://openknowledge. worldbank.org/bitstream/handle/10986/4015/WPS4818.pdf?sequence=1\&isAllowed=y (дата обращения 12.05.2020). 
7. Фокин К.В. Эволюция институтов политического авторитета: рамочная основа концепции // Полития: Анализ. Хроника. Прогноз (Журнал политической философии и социологии политики). - 2019. № 3 (94). - C. 33-54.

8. Lewis O.A., Steinmo S. How institutions evolve: evolutionary theory and institutional change // Polity. 2012. - № 44 (3). - P. 314-339.

9. Япаров С.С. Факторы, влияющие на формирование институтов // Вестник Пермского национального исследовательского политехнического университета. Социально-экономические науки. - 2017. № 1. - С. 181-192.

10. Равочкин Н.Н. Идея как инструмент социальной инженерии: философский анализ // Социодинамика. 2019. - № 12. - С. 237-255.

11. Равочкин Н.Н. Модернизация и политико-правовые институты // Вестник Кемеровского государственного университета. Серия «Гуманитарные и общественные науки». - 2018. - № 2. - С. $42-50$.

12. Равочкин Н.Н. Необходимость социально-политической модернизации // Горизонты гуманитарного знания. - 2018. - № 1. - С. 37-44.

13. Валлерстайн И. Анализ мировых систем и ситуация в современном мире. - СПб.: Университетская книга, 2001. -416 с

14. Knack S., Keefer P. Institutions and economic performance: crosscountry tests using alternative measures // Economics and Politics. - 1995. - V. 7. - № 3. - P. 207-227

15. Ebrahim Z., Irani Z. E-government adoption: architecture and barriers // Business Process Management Journal. - 2005. - V. 11. - № 5. - P. 589-611.

16. Dada D. The failure of e-government in developing countries: a literature review // The Electronic Journal of Information Systems in Developing Countries. - 2006. - V. 26. - № 1. - P. 1-10

17. Kanaan R. The Failure of E-government in Jordan to fulfill potential // International Journal of Advanced Computer Science and Applications. - 2013. - V. 4. - № 12. - P. 157-161.

18. Rodrik D., Wacziarg R. Democratic transitions produce bad economic outcomes? // American Economic Review. - 2005. - № 95 (2). - P. 50-55.

19. Sen A.K. Development as freedom. - Oxford: Oxford University Press, 1999. - 366 p.

20. Keefer P. Democratization and clientelism: why are young democracies badly governed? - Washington: World bank, Development research group, Growth and investment team, 2005. - 49 p.

21. Sen A.K. What's the point of democracy? // American Academy of Arts and Sciences Bulletin. - 2004. LVII (3). - P. 8-11.

22. McGuire M.C., Mancur O. The Economics of autocracy and majority rule: the invisible hand and the use of force // Journal of Economic Literature. - 1996. - V. 34. - № 1. - P. 72-96.

23. Olson M. Dictatorship, democracy, and development // American Political Science Review. - 1993. V. 87. - № 3. - P. 567-576.

24. Besley T., Kudamatsu M. Health and democracy // American Economic Review Papers and Proceedings. 2006. - V. 96. - № 2. - P. 313-318.

25. Alesina A., Rodrik R. Distributive politics and economic growth // The Quarterly Journal of Economics. 1994. - V. 109. - № 2. - P. 465-490.

26. Barro R.J. Democracy and growth // Journal of Economic Growth. - 1996. - V. 1. - № 1. - P. 1-27.

27. Acemoglu D., Robinson J.A. Persistence of power, elites, institutions // American Economic Review. 2008. - V. 98. - № 1. - P. 267-293.

28. Караганов С. Каким будет мир? // Российская газета. URL: https://rg.ru/2019/02/14/karaganov-mirnesmotria-na-ego-haotichnost-vpolne-predskazuem.html (дата обращения 01.06.2020).

29. Цыганков А. Трамп и кризис олигархии. URL: https://ru.valdaiclub.com/a/highlights/tramp-i-krizisoligarkhii/ (дата обращения 08.07.2020).

30. Lo Bobo. An accident waiting to happen: Trump, Putin and the US-Russia Relationship. Lowy Institute, 2020. URL: https://www.lowyinstitute.org/publications/accident-waiting-happen-trump-putin-and-us-russiarelationship (дата обращения 01.07.2020)

Поступила 09.07.2020 г. 


\title{
POLITICAL AND LEGAL INSTITUTIONS AS DRIVERS OF THE EVOLUTIONARY DEVELOPMENT OF MODERN SOCIETY
}

\author{
Nikita N. Ravochkin ${ }^{1,2}$, \\ nickravochkin@mail.ru \\ ${ }^{1}$ Kuzbass State Technical University named after T.F. Gorbachev, \\ 28, vesennyaya street, Kemerovo, 650000, Russia \\ 2 Kuzbass State Agricultural Academy, \\ 5, Markovtsev street, Kemerovo, 650056, Russia
}

Nikita N. Ravochkin, Cand. Sc., associate professor, Kuzbass State Technical University named after T.F. Gorbachev; associate professor, Kuzbass State Agricultural Academy.

The article examines the problems of political and legal institutions in the context of socio-philosophical studies related to the development of modern societies along the evolutionary path. The relevance of the study is confirmed mainly by the high level of responsibility that is assigned to the institutions under consideration in order to ensure their social order in conditions of difficult to predict world development. Thus, sociophilosophical analysis seems to be extremely necessary when drawing the contours of the general planetary situation. The subject of this research is the substantiation of the role of political and legal institutions as drivers of the modern evolutionary development of world societies. The object of the research is modern political and legal institutions. The purpose of the study is to identify the reasons for the need for political and legal institutional transformations, and clarify the importance of the institutions under consideration for evolutionary version of social development. To achieve this goal, we use our own synthetic methodology, which includes philosophical, general scientific and interdisciplinary methods, as well as a world-system approach. The reasons and factors of political and legal institutional transformations are presented. The features of the historical design of the modern alignment of forces in the world arena are considered. Through a comparative analysis, it is shown that the Sámi common models of government, autocracy and democracy, require their own conceptual rethinking, the key ideological foundations of which should be included in new versions of the social structure.

Key words: Institutions, political and legal institutions, society, evolution, modernization, development, world system.

\section{REFERENCES}

1. Ravochkin N.N. Vliyanie filosofskikh idey na politiko-pravovye instituty $\mathrm{v}$ svete istoricheskoy makrosotsiologii [The influence of philosophical ideas on political and legal institutions in the light of historical macrosociology]. Vestnik Tverskogo gosudarstvennogo universiteta. Seriya «Filosofiya», 2019, no. 2 (48), pp. 30-40.

2. Ravochkin N.N. Ideynaya determinatsiya politiko-pravovykh institutsionalnykh preobrazovaniy v XX-XXI vv. [Ideological determination of political and legal institutional transformations in the XX-XXI centuries]. Kontekst i refleksiya: filosofiya o mire i cheloveke, 2019, vol. 8, no. 4A, pp. 150-165.

3. Ravochkin N.N. Institut kak obekt sotsialno-filosofskogo analiza [Institute as an object of social and philosophical analysis]. Manuskript, 2019, vol. 12, no. 8. pp. 109-113.

4. Ravochkin N.N. Ontologicheskie i aksiologicheskie osnovaniya politiko-pravovykh novovremennykh institutov [Ontological and axiological foundations of modern political and legal institutions]. Sovremennaya nauka: aktualnye problemy teorii i praktiki. Seriya «Poznaniye», 2019, no. 5 (92), pp. 121126.

5. North D.C. Institutions. The Journal of Economic Perspectives, 1991, vol. 5, no. 1, pp. 97-112. 
6. Vollmer S., Ziegler M. Political institutions and human development does democracy fulfill its 'constructive' and 'instrumental' role? The World Bank Development Research Group Macroeconomics und Growth Team (Policy Research Working Paper 4818), 2009. 47 p. Available at: https://openknowledge.worldbank.org/bitstream/handle/10986/4015/WPS4818.pdf?sequence=1\&isAllowed =y (accessed 12 May 2020).

7. Fokin K.V. Evolyutsiya institutov politicheskogo avtoriteta: ramochnaya osnova kontseptsii [The evolution of the institutions of political authority: the framework of the concept]. Politiya: Analiz. Khronika. Prognoz (Zhurna lpoliticheskoy filosofii i sotsiologii politiki), 2019, no. 3 (94), pp. 33-54.

8. Lewis O.A., Steinmo S. How institutions evolve: evolutionary theory and institutional change. Polity, 2012, no. 44 (3), pp. 314-339.

9. Yaparov S.S. Faktory, vliyayushchie na formirovanie institutov [Factors influencing the formation of institutions]. Vestnik Permskogo natsionalnogo issledovatelskogo politekhnicheskogo universiteta. Sotsialnoekonomicheskie nauki, 2017, no. 1, pp. 181-192.

10. Ravochkin N.N. Ideya kak instrument sotsialnoy inzhenerii: filosofskiy analiz [Idea as a tool of social engineering: philosophical analysis]. Sotsiodinamika, 2019, no. 12, pp. 237-255.

11. Ravochkin N.N. Modernizatsiya i politiko-pravovye instituty [Modernization and political and legal institutions]. Vestnik Kemerovskogo gosudarstvennogo universiteta. Seriya «Gumanitarnye $i$ obshchestvennye nauki», 2018, no. 2, pp. 42-50.

12. Ravochkin N.N. Neobkhodimost sotsialno-politicheskoy modernizatsii [The need for socio-political modernization]. Gorizonty gumanitarnogo znaniya, 2018, no. 1, pp. 37-44.

13. Vallerstayn I. Analiz mirovykh system isituatsiya v sovremennom mire [Analysis of world systems and the situation in the modern world]. St. Petersburg, Universitetskay akniga Publ., 2001. 416 p.

14. Knack S., Keefer P. Institutions and economic performance: crosscountry tests using alternative measures. Economics and Politics, 1995, vol. 7, no. 3, pp. 207-227.

15. Ebrahim Z., Irani Z. E-government adoption: architecture and barriers. Business Process Management Journal, 2005, vol. 11, no. 5, pp. 589-611.

16. Dada D. The failure of e-government in developing countries: a literature review. The Electronic Journal of Information Systems in Developing Countries, 2006, vol. 26, no. 1, pp. 1-10.

17. Kanaan R. The failure of E-government in Jordan to fulfill potential. International Journal of Advanced Computer Science and Applications, 2013, vol. 4, no. 12, pp. 157-161.

18. Rodrik. D., Wacziarg R. Democratic transitions produce bad economic outcomes? American Economic Review, 2005, no. 95 (2), pp. 50-55.

19. Sen A.K. Development as freedom. Oxford, Oxford University Press, 1999. 366 p.

20. Keefer P. Democratization and clientelism: why are young democracies badly governed? Washington, World bank, Development research group, Growth and investment team, 2005. 49 p.

21. Sen A.K. What's the point of democracy? American Academy of Arts and Sciences Bulletin, 2004, LVII (3), pp. 8-11.

22. McGuire M.C., Mancur O. The economics of autocracy and majority rule: the invisible hand and the use of force. Journal of Economic Literature, 1996, vol. 34, no. 1, pp. 72-96.

23. Olson M. Dictatorship, democracy, and development. American Political Science Review, 1993, vol. 87, no. 3, pp. 567-576.

24. Besley T., Kudamatsu M. Health and democracy. American Economic Review Papers and Proceedings, 2006, vol. 96, no. 2, pp. 313-318.

25. Alesina A., Rodrik R. Distributive politics and economic growth. The Quarterly Journal of Economics, 1994, vol. 109, no. 2, pp. 465-490.

26. Barro R.J. Democracy and growth. Journal of Economic Growth, 1996, vol. 1, no. 1, pp. 1-27.

27. Acemoglu D., Robinson J.A. Persistence of power, elites, institutions. American Economic Review, 2008, vol. 98 , no. 1, pp. 267-293.

28. Karaganov S. Kakim budet mir? [What will the world be like?]. Rossiyskaya gazeta. Available at: https://rg.ru/2019/02/14/karaganov-mir-nesmotria-na-ego-haotichnost-vpolne-predskazuem.html (accessed 1 June 2020).

29. Tsygankov A. Tramp $i$ krizis oligarkhii [Trump and the crisis of the oligarchy]. Available at: https://ru.valdaiclub.com/a/highlights/tramp-i-krizis-oligarkhii/ (accessed 8 July 2020).

30. Lo Bobo. An accident waiting to happen: Trump, Putin and the US-Russia Relationship. Lowy Institute, 2020. Available at: https://www.lowyinstitute.org/publications/accident-waiting-happen-trump-putin-andus-russia-relationship (accessed 1 July 2020).

Received: 9 July 2020. 